\title{
MULTICULTURALISM AND RELIGIOUS-BASED CONFLICT: Events of Conflict Based on Ethnicity, Religion, Race, and Inter-Group Relations (SARA) in the City of Pontianak
}

\author{
Lailial Muhtifah \\ The Graduate School, Pontianak State College of Islamic Studies
}

\begin{abstract}
There is a tendency of similar idea that caught the conflict prevention and management efforts nowadays to the articles of the Charter of Medina which was religious-based and containing the theory of civil society. It I mostly on the handling of conflict which tends to take preventive measures and to stop the conflict directly, as well as making a comprehensive synergistic effort to mange conflict. Conflict prevention is a core component of a comprehensive Conflict Management Program. This paper explores the conflict that occurred in Ponianak between a group of people from ethnic Dayak and members of an Islamic organization in 2012 which includes an important lesson for the people of West Kalimantan, both for the government and the community elements especially in dealing with a dispute between different groups of people. An integrative prevention has been proven to be able to answer the question of handling a conflict that has a potential to escalate into a full-scale riot. This work concludes that an integrative conflict handling model may become a viable alternative model to be adopted by the community of West Kalimantan in particular and other societies in general. A synergic integrative conflict handling model that reflects local wisdom of the people of Pontianak is expected to inspire real peace for various communities with a multicultural background.
\end{abstract}

Key words: multicultural, religious-based conflict, ethnicity, religion

\section{INTRODUCTION}

Horizontal conflict, in this case the conflict based on ethnicity, religion, race and inter-group relations (SARA), occurs as a result of the process of marginalization of firmly-held moral standards such as religion and customs, and the unclear regulations. In the era of the industrial and cultural globalization, perhaps the most directly affected is the religious life. The recent development of religious and social life in Indonesia generally and in Pontianak, West Kalimantan particularly showed symptoms that require serious attention and need to get a major priority and efforts in social, 
cultural and religious understanding. Increased religious understanding in conjunction with socio-cultural conditions in the community has become an important factor in the integrity of the community, including the prevention of the emergence of conflict that may trigger violence or unrest in society (Prasojo, 2008).

On March 15, 2012, for example, there was a conflict in Pontianak, West Kalimantan. The conflict began when the Moreng youth started to display banners rejecting the presence of Habib Riziek from the Islamic Defenders Front (FPI) in Pontianak, West Kalimantan. The banners were installed in front of a dormitory belonging to students from ethnic Dayak on K.H. Wahid Hasyim street. As a result, a conflict associated with ethnicity, religion, race and inter-group relations (SARA) was inevitable. This paper tries to look at ways of conflict prevention and is more focused on efforts in violent conflict prevention, not specifically on the conflict event itself. This is driven by the fact that the components of the society of West Kalimantan have comprehensively managed to avert potential violent conflict in the area.

The handling of the social and religious-based conflict that occurred in West Kalimantan is faced with three major problems. First, the handling of such conflict in general tends to be militaristic in nature and has yet to have a complete instrument. Second, the conflict management conducted by both the government and non-government institutions tends to have less legal certainty. The latest development is that the academic and practical studies have yet to find a conflict management model that is more comprehensive, integrative strategic and synergistic. The factors that cause of the problem above are among others: first, the system of handling conflict developed so far has been emphasized on the preventive aspects instead of curative. Second, the handling conflict is often done in a militaristic and repressive way. Third, the legislation related to the handling of conflicts still is partial, and in the form of regulations issued by the government such as presidential instructions and regulations. Fourth, the law enforcement to prevent and resolve conflict tend to be weak because the Government Regulation (PP) on handling social conflict have yet to have a comprehensive, integrative, and synergistic format. In addition, there is no policy, in the form of Perda (regional regulations), Decree of the Mayor/Governor/Regent, that elaborates a preventive and curative process with a religious approach, and the provision of sanctions for the actors causing the conflict. Fifth, there are negative mental attitudes, such as intolerance, prejudice and religious arrogance.

Based on the description above, this study focuses on efforts in preventing conflict involving ethnicity, religion, race and inter-group relations (SARA) in 
Pontianak City, West Kalimantan. This study seeks to find a model of conflict management with a higher level of effectiveness for handling conflict involving SARA in particular, and conflict of religious teachings and movements in general. Conflict management should be conducted through prevention efforts by the Government and Non-Government organizations.

\section{CONFLICT INVOLVING SARA IN PONTIANAK REGARDING THE MARCH 15, 2012 CASE.}

\section{Conflict Prevention Efforts by the Government}

Handling conflict involving SARA that occurred on March 15, 2012 in Pontianak, West Kalimantan should be conducted through prevention efforts by all parties, including the government (city government, relevant agencies, and the Indonesian national police) and the non-government institutions (FKUB, CAIREU, FPI, MABM, YSDK, DAD, and IKBM). First, the efforts made by the Government of the city of Pontianak are as follows: 1) procedural handling; 2) handling with a security approach; 3) communicating with the religious leaders (toga), community leaders (toma), and customary elders (toa); 4) conducting the dialogue with Muslim and non-Muslim leaders; 5) making statements via text messages; 6) facilitating discussion between toga, toma and toa.

Second, the major efforts undertaken by the security are improving the performance of the police, and the army: 1) facilitating mediation; 2) realizing a program of one policeman for each village; 3) resolving certain issues through the FKPM (Police-Community Communication Forum) to reach a win-win solution; 4) empowering the bapulbaket by detecting issues circling aroung in society; 5) empowering the bapinkamtimnas which leads to FKPM; and 6) establishing good communication with toda, toma, toa, and toga.

Other efforts include: 1) keeping peace in society, 2) developing a system of peaceful settlement of disputes; 3 ) lowering the potential of conflict; and 4) setting up early warning systems. Further efforts include the use of force by the police which consists of: 1) precautions with preventive measures; 2) oral command; 3) control without weapons; 4) forceful empty hand control; 5) use of chemical weapons such as tear gas and pepper spray, or other tools in accordance with the police standard; 6) control with use of firearms or other devices to stop violent acts; and 7) looking for persons responsible for installing banners at the dormitory of the Dayak students and handing them back to the group for punishment. The police took step 1-4 to handle the conflict. It was considered successful, scoring 85 points and received an award from the national police. 


\section{Conflict Prevention efforts by Non-Government Organizations}

The efforts made by non-governmental organizations were done in collaboration with several parties. Among them are religious-based institutions. First, the Inter-religious Harmony Forum (FKUB) Pontianak and West Kalimantan Province: 1) conducting meetings with former and prospective members of the FKUB; 2) providing enlightenment to reconcile and prevent people from taking violent actions, asking them to go home, 3) emergency meeting led by the Chairman of the FKUB, 4) having dialog at local police station, 5) formulating a mutual agreement aiming for unity, peace and harmony, 6) facilitating dialog about religious unity, attended by religious leaders, community leaders, chair of the RW/RT, Sub-district Head, caretakers of worship houses, 7) having a workshop once a year.

Second, the Center for Acceleration of Inter Religious and Ethnic Understanding (CAIREU) STAIN Pontianak: 1) building communication between community leaders and customary law council, and 2) together with FKUB providing socialization on religious unity. Third, Islamic Defender Front (FPI): 1) asking for people to exercise restraint through the telephone, 2) attending a meeting at the local police station, 3) having a meeting with ethnic, religious, community leaders, Deputy Mayor, Chairman of the Malay Culture and Customary Council (MABM), Chairman of Rabittah, FKPM and FKUB Alawiyah and 4) communicating through activities to advocate for marginalized communities.

Fourth, the Malay Culture and Customary Council (MABM): attending meetings held by the police. Fifth, the Institute of Dayakology: 1) conducting enlightenment to the Dayak community (particularly the youth), 2) teaching and disseminating the message of peace and multiculturalism in seven schools under the Institute's supervision, 3) appealing to the general public not to panic. Sixth, Swadaya Dian Khatulistiwa Foundation (YSDK): 1) conducting communication, building and strengthening peace networks, appealing to not to be easily provoked. The appeal was made by communicating directly by telephone, 2) meeting with Eka Hendry (CAIREU) and several NGOs to urge te police to handle the conflict.

Seventh, the Madurese Association (IKBM): 1) asking the Madurese to exercise restraint in the pontura region as the conflict had nothing to do with religion but between the FPI and the Dayak youth, 2) attending dialog at the police station, 3 ) issuing a statement reflecting the Madurese people's stand on the issue which was also issued in 2003 (the document attached), 4) communicating with the religious leaders from all ethnic groups. Eighth, the 
academics including: 1) Prof. Dr. Syarif Ibrahim Al-Qadri through efforts of calling the chief of police, customary law elders, religious, and community leaders to resolve the conflict immediately; writing articles in the local newspaper to cool down the mass 2) Prof. Dr. Chairil Effendy and Dr. Moh. Haitami Salim, both working to prevent further conflict through meetings with religious, community and customary leaders to reconcile the parties involved.

Other efforts include appeals and advisories. The first appeal was issued by the chief of police of West Kalimantan, whose contents include: 1. the community should remain calm and not provoked by the misleading issues; 2 . the issue was a misunderstanding between different groups, not a matter of religion; 3. the matter will be handled by the security apparatus and the government; 4. people should filter the information relating to ethnicity, race, religion; 5. people are prohibited from carrying sharp weapons as stipulated by Emergency Law No. 12/1951; 6. the community should create a conducive atmosphere of security in West Kalimantan in order to return to the safe, quiet situation; 7. Conflicts that occurred several years ago brought no good to any party. The appeal was signed on March 16, 2012 in Pontianak by Drs. Unggung Cahyo who served as the chief of the regional police.

Caretakers and members of the West Kalimantan FKUB also issued a statement related to the conflict of 14 - 16 March 2012, which appealed as follows: 1 . Asking the parties involved to immediately halt the conflict for the creation of security, peace, and harmony between religious, ethnic, and community groups in the future; 2 . respecting the law, religions, religious organizations, and ethnic associations in West Kalimantan; 3. Asking all the parties involved to avoid certain political interests; 4 . Asking all the parties involved to hand the resolution of conflict to the security apparatus; 5. maintaining harmony between religious and community groups; 6 . giving appreciation and thanks to all who have made efforts to reconcile the parties involved, as well as appreciation to all the people and the leaders who have worked to stop the conflict. The statement was issued in Pontianak on 16 March 2012 and signed by 29 leaders and important persons in Pontianak.

Related to the event of conflict on March 15, 2012 in West Kalimantan, the Madurese Association (IKBM) also issued an advisory whose contents are as follows: 1 . not to bring culture or behavior that does not fit with the culture of West Kalimantan; 2. to always remember the message of the Madurese elders; 3. not to insult, harass, look down on each other; 4 . to respect each other; 5 . to resolve problems peacefully, and in the event of a dispute, not to involve ethnicity; 6. to allow legal apparatus to resolve disputes; 7. (For the law 
enforcers) to act quickly, decisively, impartially on the outlaws; 8 . To conduct a more intensive raid for liquor considering many problem it may cause. This appeal was signed on March 16, 2012 in Pontianak by the chair and secretary of IKBM.

\section{DISCUSSION ON CONFLICT PREVENTION EFFORTS}

Description of SARA-based conflict prevention efforts is analyzed based on the Islamic Studies, i.e. the theories of civil society, conflict management and socio-culture. From the perspective of the Islamic teachings, conflict prevention is based on surah in the Quran: Al-Hujuraat : 8-9, Al-Mu'minuun : 160, Al-Mumtahanah : 10, and al-Maidah : 82. Based on the viewpoint of the theory of civil society, conflict prevention efforts tend to lead to a model of "the Charter of Medina." The Charter of Medina known as "the Constitution of Medina" was a document drafted by the Prophet Muhammad, which is a formal agreement between himself and all the tribes and clans in Yathrib (later called Medina) in 622. The document laid out clear details with the main objective to stop the fierce dispute between Bani 'Aus and Bani Khazraj in Medina. For that that document sets out a number of rights and obligations for the Muslims, the Jews, and pagan communities of Medina; so as to make them unified in a community which in Arabic is called the ummah.

The analysis found the similarities between prevention efforts in handling the conflict in the city of Pontianak and that of Medina, namely: first, the prevention efforts can be made together by the Indonesian police, the government, relevant agencies, print media and society itself. They encourage the creation of peaceful situation, so they have the awareness to stop the conflict. In addition, the people of Pontianak never wanted conflict to occur. In the Charter of Medina, it is described in article 2-10, article 18, and article 44 that nine clans (the Muhajirin of the Quraisy, banu Auf, banu Sa'idah, banu Al-Hars, banu Jusam, banu Annajjar, banu Amr bin 'Awf, banu Al-Nabit, dan banu Al-Aws) collaborated to stop a fierce dispute between Banu Aus and Banu Khazraj in Madinah.

Second, security aparatuses (the Police and the Armed Forces), the Government, and FKUB should facilitate conflict prevention efforts through mediation and dialog. In Madinah, Prophet Muhammad facilitated dialog between the tribes and the Jews to stop the conflict and create a situation of peace, harmony and security. Third, in the process of mediation and dialog, they gave each other advisories, counsel, and promise (article 37 of the Medina Charter). Fourth, the handling of conflict reflects the principles of 1) Unity (article 1); 2) humanity (article 2 - 11, paragraphs 13-14); 3) impartiality and indiscrimination (article 13), 4) brotherhood (articles 15 and 16), 5) legal certainty (articles 23, 37, 40, and 42), 6) human rights (articles 25 and 46), 7) sustainability (article 42, and section 45), 8) local wisdom (articles $2-10$ ), and 9) equality and justice (articles 17 and 26-35).

The results of the analysis on conflict management theory showed 
that first, there were conflict prevention measures. Prevention of conflict according to Michael Lund (1996: 37) is "actions taken in vulnerable places and times to avoid the threat or use of force and related forms of coercion by the state or groups to resolve political disputes that can arise from the destabilizing effects of economic, social, political, and international changes." Sanam Naraghi Anderlini and Victoria Stanski concluded that prevention of conflict can be identified through actions or policies as follows: 1) actions: preventing the emergence of violent conflict and identifying ways of non-violence in resolving tensions, 2) stopping the ongoing conflict so as not to spread, and 3) detecting the reappearance of violence.

Second, there was a comprehensive effort in the conflict management. These efforts are handled through the conflict prevention efforts. Conflict prevention is a core component of a comprehensive Conflict Management Program. The conflict management program is explained in the following diagram.

Figure 1: Model for Comprehensive Conflict Prevention Initiatives

\section{Conflict Prevention Program}

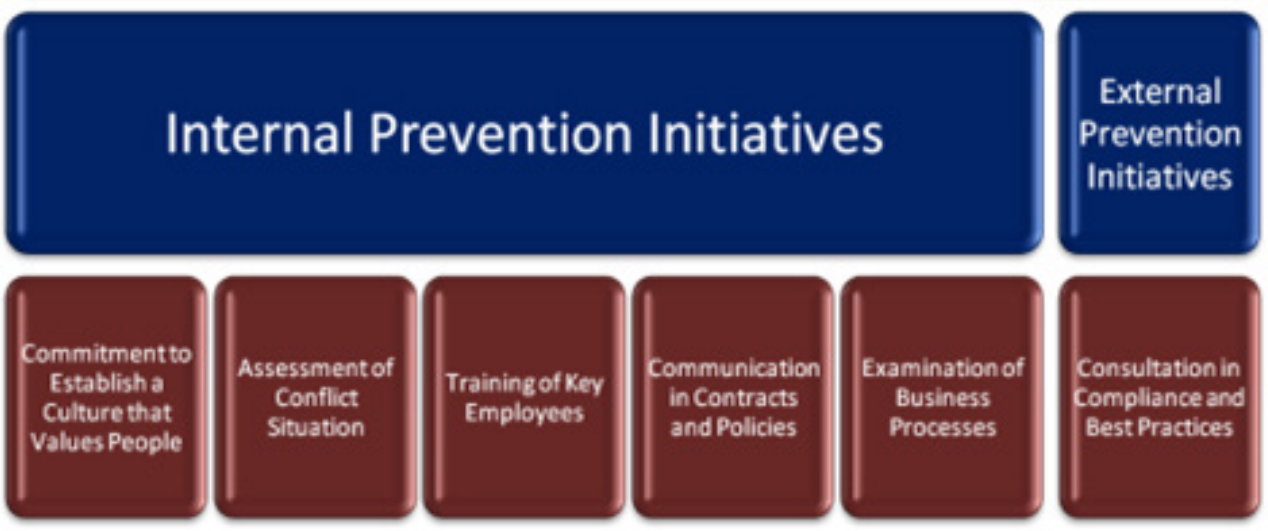

The diagram above offers a model for comprehensive Conflict Prevention Initiatives. There are five internal initiatives encouraged and one external initiative.

First of all, the concept of 'conflict' should be defined. Conflict requires incompatibility (disputed claims); the two sides are at the same time trying to get resources available to them. Conflict itself is often a constructive element of a dynamic community, but can become very problematic when the parties involved use violent means to advance their cause. However, 
conflict resolution not only requires a reduction in the use of force, but also the dissolution of the underlying incompatibilities so that conflict shall not reappear in the future. One way of preventing the parties in a conflict from fighting each other is to prevent them from using violence and to avoid the threat of military intervention. The literature on conflict prevention is largely concerned with steps that can be taken by a third party and is not coercive in nature. The principle behind the thoughts on the prevention of conflict is that conflict is a very destructive and the way of dealing with it will be expensive if the effective preventative measures are not taken earlier.

Melander, Erik; Mats Bengtsson; Patrick Kratt \& Inger Buxton (2004: 7-9) outlined that the definition of "conflict prevention" itself is not agreed between researchers. Different definitions indeed vary according to the purpose of the prevention which ranges from reducing violence to resolving discrepancies, the perspective of time (short term or long term) and means. They defined the concept of prevention in accordance with different stages of conflict when prevention is implemented. Drafting a concept of conflict into a life cycle can help to visualize how the three ideas can be applied.

Erik Melander and Claire Pigache (2004) argued that the narrow conception (sometimes referred to as primary prevention) implies prevention should happen before the violence breaks out. A broader conception (secondary prevention) includes prevention during the violence; here the conflict is more expanded. The definition according to the Boutros-Ghali fits both of these types as it pertains to prevent the dispute form escalating into an armed conflict as well as preventing it from spreading. Although the most contentious, the concept of the third (tertiary prevention) also includes postconflict peace-building so as to prevent recurrence of violence. The third conception emphasizes that the prevention of conflict in the future can be achieved "through the creation of a safe and secure environment after the achievement of a peaceful solution".

Third, handling conflict can be is done through operational prevention or deterrence. Sanam Naraghi Aderlini and Victoria Stanski outlined that the approach in the prevention of conflict consist of "operational prevention (or direct prevention) .... and structural prevention (or root causes prevention)." Direct prevention includes steps to overcome the crisis, and structural prevention is to address the root causes such as poverty, political oppression and uneven the distribution of resources; if left unattended, they may escalate into violence. Similar opinions were expressed by David Carment and Albrecht Schnabel (2004: 5) that the prevention of conflict requires structural or interactive way to keep tensions and disputes between countries from 
escalating into violence making it hard to resolve peacefully and to reduce the underlying problems including the spread of hostilities in a new place.

Fourth, conflict management according to the Rahim (2002: 208) involves the implementation of a strategy to limit the negative aspects of conflict and to increase the positive aspects at a level equal to or higher than where the conflict takes place. In addition, the goal of conflict management is to improve learning and results (effectiveness or performance in an organizational setting). It is not concerned with eliminating any conflict or avoiding conflict. Conflict can be valuable for groups and organizations. It has been proven to improve the results of the group when handled correctly (Alper, Tjosvold, \& Hukum, 2000; Bodtker \& Jameson, 2001; Rahim \& Bonoma, 1979; Khun \& Poole, 2000; DeChurch \& Marks, 2001).

Several categories are found in conflict prevention efforts from the perspective of social theory, as Parsons (2005: 59) outlined that the value oriented patterns are important in structuring the systems of action, because one of the $m$ defines reciprocal rights and obligations which are the basic elements of common expectations of the role and sanctions. Parsons believed that an agreement on the shared values is the heart of the social order. With the shared norms, such as justice and equality, people will harmonize their actions with others. In addition, people will also agree on common standards for evaluating the concrete behavior and patterns of resource allocation.

\section{CLOSING REMARKS}

Conflict prevention and management efforts nowadays tend to have similarities with the articles of the Charter of Medina which was religiousbased and containing the theory of civil society. Furthermore, the handling of conflict tends to take preventive measures and to stop the conflict directly, as well as making a comprehensive synergistic effort to mange conflict. These efforts are made through conflict prevention efforts. Conflict prevention is a core component of a comprehensive Conflict Management Program.

The conflict that occurred in Ponianak between a group of people from ethnic Dayak and members of an Islamic organization in 2012 was an important lesson for the people of West Kalimantan, both for the government and the community elements especially in dealing with a dispute between different groups of people. An integrative prevention has been proven to be able to answer the question of handling a conflict that has a potential to escalate into a full-scale riot. An integrative conflict handling model may become a viable alternative model to be adopted by the community of West Kalimantan in particular and other societies 
in general. A synergic integrative conflict handling model that reflects local wisdom of the people of Pontianak is expected to inspire real peace for various communities with a multicultural background.

\section{BIBLIOGRAPHY}

Abdullah, Imron, 2006. Studi Agama Kajian Empiris-Transendental. Cirebon: STAIN Cirebon Press.

Abdullah, Irwan, 2009. Konstruksi dan Reproduksi Kebudayaan. Yogyakarta: Pustaka Pelajar.

Fisher, Simon, dkk., 2007. Working With Conflict Skills and Strategies For Action. New York. 2007

Jurnal Manajemen, Jurnal Manajemen Sumber Daya Manusia, Bahan Kuliah Manajemen

Konflik Komunal di Indonesia Saat Ini. Jakarta: Indonesian-Netherlands Cooperation in Islami Studies (INIS) Universiteit Leiden. 2003

Modul Sosiologi, Mata Kuliah Kapita Selekta, Pokok Bahasan: System Social. Bidang Studi Public Relation, Fakultas Ilmu Komunikasi Universitas Mercu Buana, Jakarta

Lund, Michael, 1996. Preventing Violent Conflicts. Washington D.C.: United States Institute of Peace Press.

Melander, Erik, Mats Bengtsson, Patrick Kratt, and Inger Buxton, 2004. Conflict-Sensitive Development Co-operation: How to Conduct a Conflict Analysis. Stockholm: Swedish International Development Cooperation Agency.

Sanaky, Hujair AH., 2003. Paradigma Pendidikan Islam: Membangun Masyarakat Madani Indonesia. Yogyakarta: Safiria Insania Press.

Sutrisno, Mudji dan Hendar Putranto, 2005. Teori-Teori Kebudayaan. Yogyakarta: Kanisius. 2005.

Seri II: Konflik Social Bernuansa Agama di Indonesia. Jakarta: Departemen Agama RI Badan Litbang Agama dan Diklat Keagamaan Puslitbang Kehidupan Beragama Bagian Proyek Peningkatan Pengkajian Kerukunan Hidup Umat Beragama. 2003

syarif_untan.tripod.com. Makalah : Mesianisme Dalam Masyarakat Dayak di Kalimantan Barat "Keterkaitan Antara Unsur Budaya Khususnya Kepercayaan Nenek Moyang dan Realitas Kehidupan Social Ekonomi. Syarif Ibrahim al Qadrie

Tim penyusun PUSLIT IAIN Syarif Hidayatullah. Pendidikan Kewargaan Demokrasi, Ham dan Masyarakat Madani. Jakarta: IAIN Jakarta Press. 2000. 